$1-27-2008$

\title{
The Quest for Paul's Gospel: A Suggested Strategy
}

Matt Jackson-McCabe

Cleveland State University, m.jacksonmccabe@csuohio.edu

Follow this and additional works at: https://engagedscholarship.csuohio.edu/clrelst_facpub

Part of the Biblical Studies Commons, and the Christianity Commons

How does access to this work benefit you? Let us know!

Publisher's Statement

This review was published by RBL (C2008 by the Society of Biblical Literature.

\section{Recommended Citation}

Jackson-McCabe, Matt. 2008. Review of The quest for Paul's gospel: A suggested strategy, by Douglas A. Campbell. Review of Biblical Literature [http://www.bookreviews.org]

This Book Review is brought to you for free and open access by EngagedScholarship@CSU. It has been accepted for inclusion in Religious Studies Faculty Publications by an authorized administrator of EngagedScholarship@CSU. For more information, please contact library.es@csuohio.edu. 


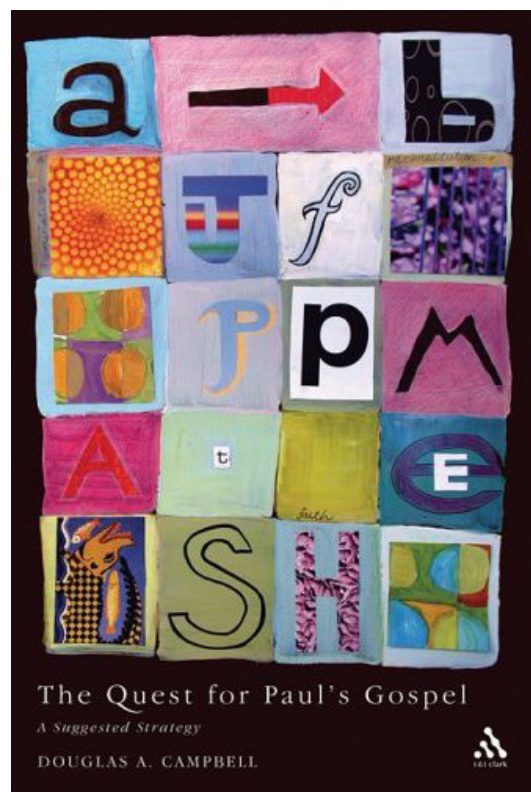

\section{Campbell, Douglas A.}

The Quest for Paul's Gospel: A Suggested Strategy

Journal for the Study of the New Testament Supplement Series 274

London: T\&T Clark, 2005. Pp. xi + 290. Hardcover.

\$140.00. ISBN 0567083322.

Matt Jackson-McCabe

Cleveland State University

Cleveland, Ohio

Scholarship on the New Testament and Christian origins has been experiencing tremendous upheaval in the decades since World War II. Particularly in the wake of the Holocaust, the question of the relation of the religion of followers of Jesus to Judaismboth in the first centuries of the Common Era and in the historical and ideological imaginations of contemporary scholars-has become a central preoccupation. Predictably, Paul and his letters are a key center in the storm. The traditional academic ("Lutheran") reading of Paul's relationship to Judaism has been under siege at least since the publication of Krister Stendahl's “The Apostle Paul and the Introspective Conscience of the West" (1961; repr. in idem, Paul among Jews and Gentiles [Philadelphia: Fortress, 1976]) and particularly since the dawning of the "New Perspective" with E. P. Sanders's Paul and Palestinian Judaism (Philadelphia: Fortress, 1977) - which was itself as much a critique of scholarly reconstructions of early Judaism as it was an argument about Paul. Douglas Campbell correctly perceives "a classic instance of a partial paradigm shift" (15) in the resulting scholarship: the traditional reading of Paul has lost its hegemony but has as yet neither been decisively refuted nor replaced by a new dominant paradigm. The result, in his view, has been a flurry of exegetical work that "often appears unsure of its overall objectives and thus of its exact contributions" (2). The intention of this book is to remedy this situation by moving discussion of Paul to what Campbell, using a military 
metaphor, thinks of as the "grand strategic level": a clear articulation of the objective of the "campaign" itself; of the basic options for attaining it; of "the most promising option"; and of "the key tactical objectives that need to be met if that option is to be prosecuted successfully" (3). The book's core thesis is that those wishing to recover Paul's gospel are best served neither by the traditional "Lutheran" reading nor the sort of salvationhistorical reading proposed by Stendahl but in a refinement of the "apocalyptic" type of interpretation offered in the early twentieth century by Schweitzer and Deissmann, now more recently by Sanders and J. Louis Martyn, a refinement Campbell calls the "pneumatologically participatory martyrological eschatology" (or "PPME") model.

The "campaign" is set up in three phases. The first (chs. 1-2) begins by outlining a method by which one can determine a coherent center in Paul's gospel, then by providing brief sketches of the live options in scholarship for explaining the nature of that gospel. Ideally, Campbell would advocate a sharpened version of J.-Christian Beker's "coherencecontingency" dialectic, which is to say, a movement from the reconstruction of "rhetorical maps" of Paul's texts to the identification of the recurrent, underlying theological premises that drive his various arguments and thus to the (possibly) coherent gospel of Paul (see 18-22). However, one can also get there via the "short-cut" of giving the letter to the Romans "a pre-eminent but not tyrannical position" (24) vis-à-vis the rest of the Pauline corpus on the assumption that Paul must give a "reasonably full account of his gospel" somewhere in it (23).

In fact, Campbell points out, each of the three main alternatives for explaining Paul's gospel is rooted in a different section of Romans. The traditional model, which Campbell dubs "JF" (justification by faith), is rooted in Rom 1-4; the PPME model is rooted in Rom 5-8; and the "salvation-historical" ("SH") model in Rom 9-11. Nevertheless, the three models are not only different from one another but "not really ultimately compatible in rational terms as soteriologies" insofar as they make "fundamentally different assumptions about reality, about salvation, and about its appropriation" (25). Only one, therefore, can be right. (The possibility that none is right in the sense that ultimately there is no single coherent gospel underlying all of Paul's writings, a possibility Campbell dubs the "AT" ["anti-theological"] approach, is said to be a last resort; see 29-34.) The upshot of all this is that success in determining which gospel model is in fact Paul's can be achieved by showing how the soteriological underpinnings of one of these sections of Romans actually explain the other two sections as well (thus eliminating the competing models or at least subordinating their concerns to a different overarching soteriology); how the resultant gospel also provides a logical basis for the ethical instruction that follows in Rom 12-15 (and for Pauline ethics more generally); and how this same gospel convincingly accounts for the various concerns articulated throughout the wider Pauline corpus. In the end, Campbell will argue not only that Paul's gospel corresponds to the

This review was published by RBL @2008 by the Society of Biblical Literature. For more information on obtaining a subscription to RBL, please visit http://www.bookreviews.org/subscribe.asp. 
PPME model but that the SH concerns are a subordinate dimension of that model, while the JF model is to be eliminated outright from his thinking.

The second stage of the "campaign" (chs. 3-7) aims to clarify the basic dynamics of the PPME model, how it bears on various issues dealt with by Paul, and its relevance for "some of our most pressing questions as his modern readers" (5). Chapters 3-4 provide a fuller explanation of the model by exploring its narrative dimension, with special attention to the question of its relation to the promise-fulfillment dynamic of the $\mathrm{SH}$ model. The PPME model is "a tale of two phases" (57), with a narrative progression from problem to solution. The initial phase, which is essentially "a modified version of Genesis 2-3," explains how sin comes to "tak[e] up residence within the very constitution of humanity, that is, in the Flesh" (57), resulting in a dark, sinister, and basically futile era. The second phase begins as Christ, in obedience to God, enters into the human condition, dies, and is then "raised to new life by the divine, life-giving Spirit, and exalted" (58). The soteriological implications of this narrative revolve around the Spirit, which was not only the instrument of Christ's resurrection in the narrative past but a "fundamentally creative" force in the present as well:

as the Spirit configures people to the template of Christ-specifically to his descent into death and ascent into glory-they too are thereby delivered from their present oppressed and corrupted condition by means of its termination in Christ's execution and their recreation in a new liberated and transformed condition that is grafted onto his resurrected existence and is now no longer inhabited by the powers of Sin and Death. (59; see 77-78 in relation to Rom 8 )

The model is thus "pneumatologically participatory" and "martyrological" in the sense that the Spirit enables a participation in the martyrological narrative; it is eschatological in the sense that the transformation it posits amounts to an "entry into ... 'the age to come" (41). From another perspective, Campbell calls it a "proto-trinitarian" gospel: though Paul has not yet arrived at Chalcedon, the dynamic of Father, Son, and Holy Spirit in his gospel represents an inchoate version of what would later be systematically formulated as orthodoxy (61; see also 41 and 64).

Although Campbell finds it useful "for heuristic purposes" to analyze the narrative dimension of Paul's gospel by moving from problem to solution, he insists emphatically and repeatedly throughout the book that the model itself does not "think" that way. On the contrary, "the model 'thinks backwards', delineating the shape of the first phase in response to the deliverance of the second" (57). Such a "retrospective" model, he argues, is fundamentally different from the "prospective" approaches of the SH and JF models, both of which are said to think forward from an a priori problem to a solution (e.g., 46-

This review was published by RBL @2008 by the Society of Biblical Literature. For more information on obtaining a subscription to RBL, please visit http://www.bookreviews.org/subscribe.asp. 
52 and passim). It is precisely this, for Campbell, that raises most forcefully the problem of the mutual compatibility of these models. The prospective objections of the SH model (What, in the end, does the PPME model say about the role of Israel?) are misplaced and, indeed, inappropriate insofar as such "prospective" concerns "would negate the role of the Christ event as Paul's central criterion" (66). Simply put, Paul's center is not salvation historical; nonetheless, his gospel still has a salvation historical dimension. The SH model, therefore, is not Paul's gospel but simply a subordinate element of the PPME model: "a second moment of discernment and recovery following the initial, primary disclosure of what is absolutely fundamental in relation to Christ and the Spirit" (67).

Chapters 5-7 go on to show how the PPME model illuminates other parts of the Pauline corpus, including Paul's ethical teaching. In chapter 5 Campbell focuses on Gal 3:28, arguing that, "correctly understood," it can be seen to "articulat[e] the PPME model clearly and compactly" (94); put another way, "chapters 5-8 of Romans are Gal. 3.26-28 writ large" (110, emphasis original). At the same time, Gal 3:28 makes it quite clear that "certain dramatic ethical actions" (94) are implicit in and intrinsic to that model insofar as it is "irreducibly radical, abolitionist, and therefore also political and liberational" (104). Chapter 6 explores the relevance of that ethical thrust for contemporary Christians by applying it to the "case study" of gay ordination. Chapter 7 rounds out this portion of the book by bringing the PPME model to bear on the question of "Paul's Gospel, Judaism, and the Law," arguing that the retrospective structure of the PPME model provides a more useful reading of Paul's gospel in a post-Holocaust setting, offering "a kinder, gentler evangelism" (144).

In the final phase of book (chs. 8-11) Campbell turns his attention to the JF model, specifically to eliminating it from the explanation of Paul's gospel altogether. Chapter 8 presents a detailed examination of the basic dynamics of the model as an abstract theological system, with special attention to the problems it creates for contemporary Christian interpreters. To this end, he uses theologian J. B. Torrance's analysis of Federal Calvinism, the "contractual soteriology" of which is also said to be the heart of - and a principle source of problems for-the JF model. Chapters 9 and 10 look specifically at the JF model's understanding of pistis, particularly vis-à-vis the pistis Christou debate. Chapter 9 argues that the JF model's "anthropocentric" (objective genitive) interpretation of pistis causes a number problems that are eliminated by the "christocentric" or "trinitarian" pistis of the PPME model, in which "'faith' is ... derived through participation in the second Adam, Christ" (200). Chapter 10 then zeros in on Gal 3, which is said to be "perhaps the most decisive text" for the pistis Christou debate (208). Here Campbell argues that a "context sensitive reading" suggests a "christocentric" (subjective genitive) interpretation in which "the pistis" is basically another way of talking about what is elsewhere referred to as "the seed," namely, Jesus Christ himself (see 211).

This review was published by RBL @2008 by the Society of Biblical Literature. For more information on obtaining a subscription to RBL, please visit http://www.bookreviews.org/subscribe.asp. 
Thus "Gal 3.15-29 offers not merely a possible but a decisive victory for PPME readings of the data of 'faith' in Paul" (9).

Chapter 11, finally, represents "a preliminary skirmish" into "the main exegetical battle for the future of the JF model," namely, Rom 1:18-3:20. It begins by explaining the traditional (i.e., JF) reading of the text and arguing that it is riddled with fundamental problems. Campbell then offers the outlines of an alternative reading that is both expressive of the PPME model and free of all the problems he finds endemic to the JF interpretation. The crux of the matter is Campbell's contention that this portion of Romans represents Paul's critique of a "turn or burn" gospel (e.g., 248, 249) of retributive justice that was apparently circulating in Rome. The outlines of the "meritocratic soteriology" with which Romans begins, then, is not a rehearsal of Paul's own preaching but "a masterpiece of ironic subversion" (233): Paul, "mimicking" his opponents, begins with an articulation of "a position that he intends to savage" $(246,47)$. Ironically, then, the "prospective" principle of retributive justice on which the JF model is based is scarcely reflective of Paul's own gospel; on the contrary, it finds its way into Romans only because Paul wanted to dismantle it. In fact, when Paul's gospel is seen apart from such "a-priori prospective" commitments, "he himself ends up as a clearer, sharper, simpler and rather more intelligent figure" (261).

There are a number of merits to this provocative book. Perhaps the most significant of these is its ability to move beyond the limited terms of the debate between traditional and New Perspective interpretations of Paul to a more concrete discussion of the actual soteriological mechanism at work in the Pauline literature. What is more, in this reader's view at least, Campbell gets much of the big picture quite right. In particular, his recognition of the centrality of "the Spirit" to the mythic system reflected in Paul's letters is a clear advance over so much past scholarship, where the concept is frequently relegated to the margins. (Placing Paul's thought on a trajectory toward Chalcedon, however, arguably does more to muddy the waters than to clarify them!) What is more, the point that this notion of "Spirit" is intimately bound up, in a way that the JF and SH models are not, in the issue of Pauline praxis-both ethical, which is an underlying concern of the book, and ritual, in which it is much less interested-is an important one that might well be further developed in conversation with those recent works that have drawn on comparative studies of spirit possession cults in order to illuminate Paul's religion.

At the same time-and ironically, given its preeminent concern with the "grand strategic level"- the book suffers from a certain ambiguity regarding its ultimate objective. On the one hand, the "overarching goal" of the book is identified simply as "find[ing] Paul's Gospel" (262)-seemingly a patently descriptive and historical task. Yet it is quite clear

This review was published by RBL @2008 by the Society of Biblical Literature. For more information on obtaining a subscription to RBL, please visit http://www.bookreviews.org/subscribe.asp. 
from the outset that this is in fact only a part of Campbell's project, apparently not even the most important one. The accurate description of Paul seems instead to be subordinate to Campbell's larger concern to ensure that the Pauline literature remains relevant for contemporary Christians. That is, the book more specifically aims "to make the right grand strategic decisions in relation to the successful and constructive theological explanation of Paul" (3, emphasis added). In this respect the stakes would seem to be much higher than a simple academic attempt to "get it right," for the very survival of Christianity as we know it is said to hang in the balance (30). "To lose [Paul] is potentially to lose everything" (2). Campbell thus promises not only a more historically accurate Paul but "a more useful Paul ... a rather kinder apostle, with a more liberative, constructive, and cogent gospel” (28).

To be sure, from Campbell's point of view, the search for a historically accurate Paul may well be one and the same as the search for a Paul that is a constructive force for the twentyfirst century; he begins, after all, from the assumption that Paul's gospel corresponds to the actual structure of cosmic reality (e.g., 12-13; see also 32, where it is asserted that the heart of Paul's gospel, in the end, is "not actually a conceptual or linguistic construct at all" but "the set of relationships and divinely conditioned experiences to which that construct points"). But the casual interweaving of historical, descriptive analysis with normative, constructive analysis seriously limits the usefulness of the book for anyone who does not begin his or her exegesis of Paul within Campbell's dogmatic hermeneutical circle. For example, as noted above, Campbell argues against the validity of the SH model due to its "prospective" approach. Such an approach, he argues, is "a grievous error that must be resisted" for a number of reasons:

First, it would negate the role of the Christ event as Paul's central criterion, which is unacceptable in and of itself, and on both textual and theological grounds.... Secondly, it would also probably be ineffective. Our affirmations of the permanence of a particular element within creation have no real eschatological validity or status because we are not the agent who will effect the eschaton. Hence, in all honesty, we have to admit that we do not really know what elements within creation and its history will ultimately be preserved.... Thirdly, it is to adopt a position that is itself fundamentally insecure. Since the Enlightenment, the fragility of all a-priori theological claims ... have been ruthlessly exposed. (66-67, emphasis original)

Here the discussion shifts seamlessly from the properly historical question of what Paul believed to the normative issue of what "we" should believe. But even if "we" should approach the question of eschatological realities with humility, does that mean that Paul did? And what bearing, from a historical point of view, does post-Enlightenment

This review was published by RBL @2008 by the Society of Biblical Literature. For more information on obtaining a subscription to RBL, please visit http://www.bookreviews.org/subscribe.asp. 
epistemology have on the interpretation of the discourse of a first-century Jewish devotee of Jesus? Despite the nod to textual concerns here, these arguments have little to do with interpreting Paul-at least apart from a starting assumption that our contemporary "truths" must surely also be reflected also in his own (true) writings. Such concerns are at times so dominant as to render whole sections of the book essentially irrelevant to the historical analysis of Paul (esp. chs. 6-8); elsewhere, it is left to the reader to try to disentangle the properly historical arguments from the normative, theological ones within the general argument of the book.

That Campbell's interest in historical reconstruction is in fact subordinate to his constructive theological project becomes clear at several points. The treatment of the key issue of "Paul's Gospel, Judaism and the Law" in chapter 7, for example, is presented above all as a lesson in "the perils of a prospective analysis" and the merits of a "retrospective" one in a post-Holocaust era (144). If one approaches theology retrospectively, it is argued, then one is not committed to any particular construal of Judaism before Christianity, let alone the overtly negative appraisal assumed by the JF model. Regardless of the merits of that argument, the question that is surprisingly neglected here is what is actually said in the Pauline letters about Judaism both before and after the death of Jesus and the advent of "the Spirit." Indeed, the assumption would seem to be that this is not a question with which "we" (i.e., the presumed disciples of Paul) need to be overly concerned, given the relative unimportance of the matter within a retrospective gospel. (Cf. in this respect 1079, where it is argued that the specific "Hellenistic antitheses" enumerated in Gal 3:28 are "largely detachable from [Paul's] christological claims," i.e., from his gospel [emphasis original]).

One finds a similar, if more subtle, dynamic at work in the crucial treatment of Rom 1-3 in the book's final chapter. A core concern of this chapter is to show that the historically (and ethically) problematic description of early Judaism assumed by the JF model, and seemingly reflected above all in Rom 1-3, is not in fact characteristic of Paul himself. Campbell's thesis is that Paul "is not himself engaging in these outrageous redefinitions of Judaism" but is opposing other Jewish Christian teachers who are (252). This, however, scarcely resolves the historical problem generated by the passage. Why is it any less problematic to assign such a peculiar view of Judaism to other first-century Jewish devotees of Jesus? To marginalize these figures as "a couple of renegade, overzealous Jewish Christians" who are not actually "representative of Judaism" (248) scarcely solves the problem, for might not Paul himself be described the same way? And if Campbell can so readily imagine that these other teachers may not actually have been aware of the implications of their "meritocratic" outlook for the issue of Israel's covenant with God and that they indeed "almost certainly" combined this particular teaching with "various other soteriological principles" in a perhaps less-than-coherent manner (248), why is it so

This review was published by RBL @2008 by the Society of Biblical Literature. For more information on obtaining a subscription to RBL, please visit http://www.bookreviews.org/subscribe.asp. 
terribly difficult to imagine that the same could be said of Paul? Here we apparently led back to the dogmatic assumption regarding the revealed truth of one of these gospels, but not the other. In any case, Campbell once again seems less interested in cogent historical reconstruction than in getting Paul "off the hook" (an expression he uses twice in this connection; see 248, 252). If "the reader can now experience a great sense of interpretive relief" (252) with the distancing of Paul himself from this troubling view of Judaism, Campbell has basically accomplished what he has set out to do. The historical problem of explaining how a first-century Jewish teacher could have come to this perception of Judaism is suddenly beside the point.

In sum, the reader will want to approach this book aware of what it is and of what it is not. Despite its title, in the final analysis this study is less a quest for Paul's gospel than for a contemporary Pauline theology, a Pauline theology that is workable in a postHolocaust, and more generally postmodern, era. One would expect that its provocative assault on traditional (especially Lutheran) constructions of Paul will be of great interest to Christian theologians and those who consider themselves disciples of the apostle in particular. For those interested simply in the historical redescription of Pauline religion, however, the work holds limited interest. 